\title{
Dorosłe dzieci alkoholików
}

\section{Dorastanie w rodzinie z problemem alkoholowym}

\subsection{Sytuacja dziecka w rodzinie z problemem alkoholowym}

Życie dziecka w rodzinie, w której jedno lub oboje rodzice nadużywają alkoholu, jest trudne i nieprzewidywalne. Żyje ono w ciągłym chaosie, nie mogąc przewidzieć, co się wydarzy. Jednego dnia tata zachowuje się normalnie, a następnego dzieją się z nim dziwne rzeczy - krzyczy, bije, wygląda na chorego. Dziecko nie rozumie takiej przemiany, a reszta rodziny zajęta alkoholikiem nie potrafi lub nie chce mu tego wyjaśnić. Jeżeli pod wpływem alkoholu rodzic staje się agresywny, używa przemocy, to dziecko jest w jeszcze trudniejszej sytuacji. Osoba, która powinna dawać mu poczucie bezpieczeństwa, wsparcie, opiekę, staje się źródłem zagrożenia.

$1 \quad$ Ukończyła studia na Uniwersytecie Papieskim Jana Pawła II w Krakowie na kierunku Nauki o rodzinie - specjalność poradnictwo i mediacje. Obecnie pracuje w Szpitalu Specjalistycznym im. dr. J. Babińskiego w Krakowie jako terapeuta w Zespole Wsparcia Duchowego. Jest kuratorem społecznym. 
Dziecko zaczyna wtedy odbierać taką sytuację rodzinną jako coś niepoddającego się kontroli, czuje się bezradne ${ }^{2}$.

Podstawowe doświadczenia, które towarzyszą dzieciom wychowanym $\mathrm{w}$ rodzinach $\mathrm{z}$ problemem alkoholowym, to: chaos, nieprzewidywalność zachowań, bezradność, poczucie zagrożenia, dezorientacja, brak wsparcia, poczucie odrzucenia, brak zrozumienia sytuacji, poczucie izolacji społecznej, brak dobrych wzorców, brak spójnego systemu norm i wartości, złość i agresja. Te wszystkie odczucia w każdej fazie rozwoju człowieka - od dzieciństwa przez okres dorastania aż po dorosłość - mają na niego ogromny wpływ ${ }^{3}$.

\subsection{Dziecko we wczesnym okresie rozwoju w rodzinie alkoholowej}

Rozwój dziecka we wczesnym okresie dzieciństwa jest w dużej mierze zależny od jego aktywności własnej oraz od jakości relacji z matką. Ojciec przez pierwsze dwa lata życia dziecka pełni najczęściej funkcję polegającą na zabezpieczeniu materialnym rodziny i udzielaniu wsparcia matce; dopiero później staje się dla niego postacią bardziej znaczącą.

Nadużywanie alkoholu przez ojca, gdy dziecko jest we wczesnym okresie rozwoju, wpływa przede wszystkim na stan psychiczny matki. Może to spowodować wiele napięć związanych z koniecznością samotnego zmagania się z piciem męża i brakiem wsparcia emocjonalnego dla niej jako partnerki i młodej matki. Doświadczenia dziecka w relacji z nią są podstawą tworzenia się wewnętrznych modeli przywiązania, które determinują jego rozwój. Jeśli są one pozytywne, czyli matka jest zaangażowana i wrażliwa na potrzeby dziecka, wtedy

2 Por. A. Hebenstreit-Maruszewska, Dorosłe Dzieci Alkoholików, Warszawa 2010, s. 2.

3 Por. A. Hebenstreit-Maruszewska, Dorosłe Dzieci Alkoholików, dz. cyt., s. 2. 
kształtuje się bezpieczny styl przywiązania. Jeśli zaś nie angażuje się ona w utrzymywanie relacji z potomkiem, jest nieobecna albo zachowuje się w sposób chaotyczny, wtedy tworzą się pozabezpieczne style przywiązania ${ }^{4}$.

Mary Ainsworth wyodrębniła trzy podstawowe style przywiązania: bezpieczny, unikający i ambiwalentny. Pierwszy z nich daje dzieciom duże poczucie własnej wartości oraz raczej pozytywne postrzeganie innych ludzi i sytuacji. Są ufne i w relacjach z innymi ludźmi czują się bezpiecznie, w trudnych sytuacjach potrafią zwrócić się o pomoc. Dzięki zdolnościom do wyrażania emocji są wyraziste i komunikatywne, potrafią przystosować się do wymagań otoczenia i nie cierpią $\mathrm{z}$ powodu lęku przed odrzuceniem ${ }^{5}$.

Dzieci o unikającym stylu przywiązania ignorują obecność rodzica, unikają bliskości i kontaktu. W stosunku do innych osób czują niechęć, pogardę i przypisują im najczęściej złe intencje. Starają się być samodzielne, ponad wszystko zaprzeczając przy tym potrzebom zależności i kontaktu emocjonalnego. Bardziej negatywnie odbierają innych niż siebie. Ich mechanizm obronny polega na tworzeniu reakcji przeciwnych do własnych odczuć: zamiast zależności eksponują pozorną niezależność, a za powierzchownym zadowoleniem często ukrywają złość 6 .

Ambiwalentny styl przywiązania dotyczy dzieci, które usilnie poszukują bliskości, ale gdy ona się pojawia, odczuwają często lęk i wstyd, co wywołuje ogromne pokłady gniewu i agresji. Charakteryzują się niskim poczuciem własnej wartości, bardzo boją się odrzucenia i rozstania. Nie potrafią zwrócić się o pomoc do innych w sytuacji,

4 Por. E. Aronson, T. D. Wilson, R. M. Akert, Psychologia społeczna. Serce i umysł, tłum. J. Cilewicz, Poznań 1997, s. 442-444.

5 Por. E. Aronson, T. D. Wilson, R. M. Akert, Psychologia społeczna, dz. cyt., s. 442444.

6 Por. L. Cierpiałkowska, M. Ziarko, Psychologia uzależnień - alkoholizm, Warszawa 2010, s. 258. 
gdy odczuwają stres czy lęk. Często w takich momentach, kiedy nie wiedzą, jak sobie poradzić, manipulują otoczeniem ${ }^{7}$.

Na podstawie badań wyodrębniono także zdezorganizowany wzorzec przywiązania, związany ze szczególnie drastycznymi doświadczeniami porzucenia, wykorzystania seksualnego, maltretowania psychicznego bądź fizycznego ${ }^{8}$. Dzieci funkcjonują w sposób chaotyczny z powodu braku spójnego obrazu siebie i innych. Cierpią z powodu silnych lęków związanych z postrzeganiem świata zewnętrznego jako niebezpiecznego. Są rozchwiane emocjonalnie i pozostają takie, będąc dorosłymi ludźmi.

Wśród dzieci alkoholików istnieje duże prawdopodobieństwo do ukształtowania się pozabezpieczanych stylów przywiązania. Na podstawie badań okazało się, że dzieci z rodzin alkoholowych różnią się od swoich rówieśników stylem przywiązania i częściej ujawniają styl zdezorganizowany niż bezpieczny.

\subsection{Funkcjonowanie dzieci w okresie adolescencji i wczesnej dorosłości}

Dorosłe dzieci alkoholików, zgłębiając swoją przeszłość i uzyskując pomoc $w$ trakcie różnych form terapii, często decydowały się na szkolenia $\mathrm{w}$ zakresie pomocy osobom o podobnych problemach. Dzięki temu zaczęły powstawać liczne opisy kliniczne dotyczące funkcjonowania tej grupy, szczególnie w okresie dorastania i wchodzenia w dorosłe życie?

Janet Geringer Woititz w swojej książce Dorosłe dzieci alkoholików zawarła całe kompendium wiedzy dotyczące tej problematyki. Według autorki dzieci alkoholików wychowują się w rodzinach,

7 Por. L. Cierpiałkowska, M. Ziarko, Psychologia uzależnień..., dz. cyt., s. 259.

8 Por. L. Cierpiałkowska, M. Ziarko, Psychologia uzależnién..., dz. cyt., s. 258-259.

9 Por. A. Widera-Wysoczańska, Pijany dom, czyli co dzieje się z dzieckiem alkoholika, [w:] Cdzie się podziało moje dzieciństwo. O dorosłych dzieciach alkoholików, red. P. Żak, Kielce 2006, s. 13-16. 
w których nikt nikogo nie szanuje i nie określa granic tego, co wolno robić, a czego nie. $Z$ tego powodu tak trudno im jest cenić siebie i innych. Na podstawie spostrzeżeń Woititz, pracującej z dziećmi alkoholików przez wiele lat, można opisać je następująco ${ }^{10}$ :

- Dzieci alkoholików zgadują, co jest normalne. Rodziny z problemem alkoholowym nie potrafią przekazać im informacji na ten temat. Funkcjonowanie w takim domu jest chaotyczne, nie wiadomo, jak powinny wyglądać relacje i komunikacja z innymi albo jak należy się zachować w konkretnych sytuacjach.

- Dorosłe dzieci alkoholików mają trudności w konsekwentnej i skutecznej realizacji dążeń. Dzieci w rodzinach z problemem alkoholowym często doświadczały obietnic bez pokrycia. Uczą się przez to, że stawiane sobie cele nie muszą być zrealizowane, bo i tak nikt nie zwraca na to uwagi. Często odkładają wykonanie zaplanowanych zadań i nie dostrzegają w tym nic niestosownego.

- Dorosłe dzieci alkoholików kłamią, gdy prościej jest powiedzieć prawdę. Funkcjonowanie rodziny z problemem alkoholowym opiera się przede wszystkim na kłamstwie. Nikt nie mówi tego, co naprawdę myśli, czuje, a $\mathrm{z}$ czasem jest to na tyle utrwalony mechanizm, że występuje nawet wtedy, gdy nie ma powodów do skrywania swoich przeżyć.

- Dorosłe dzieci alkoholików formułują bardzo surowe i kategoryczne oceny. Krytyka wobec dzieci jest nieodłącznym elementem w rodzinie alkoholowej, mimo że starają się one sprostać oczekiwaniom rodziców. Konsekwencją tego jest odnoszenie się do siebie i innych bezlitośnie i bardzo krytycznie.

- Dorosłe dzieci alkoholików mają duże trudności z przeżywaniem radości i zadowolenia. Życie w takiej rodzinie jest często smutne i przygnębiające, nie ma w nim miejsca na radość i zabawę. Dzieci 
bardzo wcześnie muszą stać się dorosłe i samodzielne, więc różne sprawy traktują bardzo poważnie.

- Dorosłe dzieci alkoholików trudno nawiązują bliskie relacje. Rodzinne doświadczenia powodują, że w kontaktach interpersonalnych czują się zagrożone lub poszukują idealnego partnera. Najczęściej nie posiadają wiedzy na temat tego, jak powinny wyglądać zdrowe, stabilne relacje, co jest powodem wielu bolesnych rozczarowań.

- Dorosłe dzieci alkoholików przesadnie reagują na zmiany, na które nie mają wpływu. Od najmłodszych lat próbują kontrolować i przejmować odpowiedzialność za innych członków rodziny, myśląc, że mają jakikolwiek wpływ na zdarzenia zewnętrzne. Jeśli w ich życiu pojawi się zbyt gwałtowna zmiana, często odczuwają lęk przed utratą nad nim kontroli.

- Dorosłe dzieci alkoholików nieustannie poszukują potwierdzenia własnej wartości. Komunikaty rodziców w rodzinach alkoholowych są zazwyczaj niejasne, nasycone bardziej złością i lękiem niż bezwarunkową miłością. Konsekwencją tego jest kształtowanie się u dziecka niskiego poczucia własnej wartości oraz potrzeby uznania.

- Dorosłe dzieci alkoholików są przekonane, że różnią się od wszystkich. Jest to wyniesione z dzieciństwa, kiedy dziecko musiało ukrywać to, co dzieje się w rodzinie. Ujawnienie sekretu groziłoby samotnością, doznaniem wstydu. Poczucie odmienności jest też przejawem braku utożsamienia się z grupą rówieśniczą.

- Dorosłe dzieci alkoholików są nadmiernie odpowiedzialne albo nieodpowiedzialne. Nadmierna odpowiedzialność cechuje osoby, które w dzieciństwie przejmowały funkcje należące do rodziców. Dzięki temu czuły się dowartościowane i w dorosłym życiu powtarzają te wzorce. Jeśli zaś przeżywały zbyt dużo porażek, przestają się starać i robić cokolwiek.

- Dorosłe dzieci alkoholików są niezwykle lojalne, także w sytuacji, gdy druga osoba jest nielojalna. Dzieci w rodzinach alkoholowych często dorastają w przekonaniu, że nie pozostawia się drugiej 
osoby, choćby życie z nią było destrukcyjne. Z tego powodu jako dorośli pozostają w niesatysfakcjonujących związkach, również obawiając się zmiany.

- Dorosłe dzieci alkoholików ulegają impulsom. Członkowie rodziny z problemem alkoholowym zwykle reagują impulsywnie, zamiast postępować zgodnie z wyznaczonym celem, planem. Takich zachowań uczą się dzieci, które w dorosłości często podejmują decyzje pod wpływem chwili, bez zastanowienia.

\section{Przystosowanie się dziecka} w rodzinie z problemem alkoholowym

\subsection{Kształtowanie się postawy obronnej u dziecka}

Poczucie bezpieczeństwa dzieci z rodzin z problemem alkoholowym, jakie powinni dawać im rodzice, jest często zaburzone. Doświadczają one więcej napięć, lęku i samotności niż rówieśnicy z normalnych rodzin. Ten stan sprzyja tworzeniu się obronnej postawy życiowej.

Postawa obronna jest przeciwieństwem postawy otwartej i ufnej aktywności. Nie sprzyja ona żadnym zmianom, każe wystrzegać się ryzyka. W postawie obronnej człowiek zamyka się, a w tej przeciwnej eksperymentuje, próbuje. $\mathrm{Z}$ tego powodu w dorosłości tak trudno dzieciom alkoholików przychodzi podjęcie decyzji o jakiejkolwiek zmianie w swoim życiu. Żyjąc w rodzinie z problemem alkoholowym, dzieci dostają mniej lub więcej wsparcia od rodziców, co jest najczęściej uzależnione od ich indywidualnych możliwości. Zależnie od ilości czynników wpływających na taką rodzinę efekty tworzenia się postawy obronnej są u nich różne ${ }^{11}$.

11 Por. W. Sztander, Dzieci w rodzinie z problemem alkoholowym, Warszawa 1993, s. 4-6. 


\subsection{Trzy nauki}

Większa część energii członków rodziny z problemem alkoholowym jest pochłonięta obecnością osoby uzależnionej wśród domowników. Często pojawia się potrzeba wyparcia problemu, ale niestety z tym wiążą się jeszcze większe utrudnienia. Dlatego najczęściej rodzina dostosowuje się do sytuacji, w jakiej się znalazła. Wymaga to poważnych wysiłków organizacyjnych i psychicznych, by ustalić na nowo wzajemne relacje w takim układzie ${ }^{12}$.

Dziecko w rodzinie z problemem alkoholowym, by dostosować się do zastanej rzeczywistości, uczy się trzech podstawowych za$\mathrm{sad}^{13}$, które stają się motywem przewodnim jego życia, zapewniając mu przetrwanie:

- Nie ufać

Jest konkluzją i intuicją wobec życia w chaosie oraz urazów, jakie oferuje rodzina z problemem alkoholowym. Dziecko uczy się ufności i tego, jak powinno wyglądać życie, od rodziców. W sytuacji uzależnienia dorosłych nie ma w nich oparcia, więc czuje się niepewnie i staje się podejrzliwe. Podejrzliwość sprawia, że ma ono ograniczone możliwości nie tylko w konfrontowaniu się z uczuciami innych, ale również w wyrażaniu własnych. Stanowi to ogromną trudność w dorosłym życiu, gdyż nieświadomość własnych uczuć utrudnia nawiązywanie relacji z innymi ludźmi. Niespełnione obietnice i niedotrzymane umowy rodziców budzą w dziecku nieufność nie tylko do nich, ale też do całego świata ${ }^{14}$.

Por. T. Hellsten, Wsparcie dla dorosłych dzieci alkoholików. Hipopotam w pokoju stołowym, Łódź 2006, s. 41-43. 
- Nie mówić

Taki komunikat najczęściej słyszą dzieci od rodziców w sprawach związanych z problemem alkoholowym. Milczenie jest równoznaczne z udawaniem, że wszystko jest w porządku. Dzieci zazwyczaj, mimo fatalnego traktowania, są bardzo lojalne wobec swoich opiekunów. Nie mówi się o tym, że tata pije, tylko że źle się czuje. Z matką, która wygląda na zatroskaną, też raczej nie należy rozmawiać, bo poruszy się temat tabu. Często dziecko okłamuje samo siebie, by się uspokoić i nie rozbudzać w sobie przykrych emocji. Zasada ta dotyczy także nieporuszania tematów związanych $z$ rodziną z obcymi osobami, co oznacza zupełny brak pomocy z zewnątrz. Dzieci alkoholików trzymają rodzinną tajemnicę w sobie niczym skarb, często ze wstydu, strachu lub w nadziei, że będzie lepiej. Konsekwencją tego jest wielka samotność dziecka w rodzinie z problemem alkoholowym $^{15}$.

- Nie odczuwać

Ta zasada jest twardym pancerzem, który pozwala chronić dziecko przed ciosami. Szybko uczy odcinać się i znieczulać wobec przerażających je uczuć czy nieprzewidywalnych zachowań rodziców. Nie potrafi sobie poradzić z uczuciami uporczywej złości czy nienawiści wobec matki lub ojca, dlatego oddala je od siebie. Zdarza się, że takie osoby same starają się wmówić sobie, że owych przeżyć czy doświadczeń nie posiadają, aby poczuć się bezpieczniej. Takie zachowanie, często powtarzane, może grozić odłączeniem się od własnych emocji i prawdziwych uczuć. Zafałszowanie ich oraz rzeczywistości powoduje osłabienie „czujnika” emocjonalnego, który w dorosłym życiu pozwala na orientację w świecie. Jest to bardzo trudna psychologicznie sytuacja 
i najbardziej destruktywna forma przystosowania się do życia $\mathrm{w}$ rodzinie $\mathrm{z}$ problemem alkoholowym ${ }^{16}$.

\subsection{Cztery podstawowe role umożliwiające przetrwanie}

Postawa obronna i odejście od samego siebie mogą kształtować w ludziach sztywne, schematyczne sposoby działania, narzucać pewne skorupy, pod którymi mogą się schować, bo chociaż nie są wygodne, to pozwalają na unikanie kontaktu z bolesną rzeczywistością. Oprócz posługiwania się trzeba zasadami: „Nie mów”, „Nie ufaj”, „Nie odczuwaj" dzieci wychowane w rodzinie z problemem alkoholowym wchodzą zazwyczaj w takie role, które możliwie najlepiej pomagają im dostosować się do sytuacji. Wymienienie kilku podstawowych ról może być dużym uproszczeniem, ale pozwala zrozumieć konsekwencje takich wzorów funkcjonowania, by służyć systemowi rodzinnemu ${ }^{17}$.

\section{Bohater rodzinny ${ }^{18}$}

Rola ta przypada najczęściej najstarszemu dziecku, bez względu na płeć. Od najmłodszych lat oczekuje się od pierworodnego syna lub córki sukcesów we wszystkich sferach działania, a wraz z dorastaniem - udzielania pomocy i wsparcia wszystkim członkom rodziny. Pierwsze dziecko ma wyjątkową pozycję, jest zwykle oczekiwane nie tylko przez rodziców, ale również dziadków. Rodzina poświęca mu dużo czasu, licząc też, że gdy pojawi się dziecko, „ustatkuje się" osoba uzależniona. Bohater rodzinny rezygnuje z osobistych celów

Por. W. Sztander, Dzieci w rodzinie z problemem alkoholowym, dz. cyt., s. 12-14.

Por. M. Kucińska, DDA, czyli dorosłe dzieci alkoholików, [w:] Gdzie się podziało moje dzieciństwo, dz. cyt., s. 45.

Por. L. Cierpiałkowska, M. Ziarko, Psychologia uzależnień..., dz. cyt., s. 263-265. 
życiowych, by godzić rodziców, opiekować się młodszym rodzeństwem, robić wszystko, żeby inni mieli lżej. Głównie dzięki jego staraniom rodzina może nadal funkcjonować, zachowując pozory normalności i stabilności. Bohater szybko staje się dorosły, stara się być perfekcyjny we wszystkim, co robi, nie pozwala sobie na okazywanie słabości, nigdy się nie usprawiedliwia. Dalsza rodzina i znajomi często chwalą takie dziecko i podziwiają, dzięki czemu rodzice mogą czuć zadowolenie, że wychowali tak odpowiedzialnego młodego człowieka. Bohater późno zaczyna sobie zdawać sprawę z tego, że ojciec jest alkoholikiem, a wiele problemów w rodzinie stanowi tego konsekwencję. Tylko czasem ktoś zauważy, że bohater to bardzo skryte dziecko, wiecznie niezadowolone z siebie i z tego, co zrobiło. Czuje się zaniedbany, osamotniony, odmawia sobie prawa do szukania i przyjmowania jakiejkolwiek pomocy z zewnątrz. Rodzice wymagają od niego, żeby zachowywał się dorośle, ale dziecko, które nie przeszło pełnego cyklu dorastania, nie jest w stanie sprostać temu żądaniu. W życiu dorosłym bohater nadal realizuje scenariusz swojej roli. Zwykle zajmuje wysokie stanowisko, jest powszechnie ceniony, obowiązkowy. Bywa często samotny, nawet gdy zakłada własną rodzinę; z dużą trudnością przychodzi mu utrzymywanie bliskich, intymnych kontaktów. Ma skłonność do różnych chorób psychosomatycznych.

\section{Kozioł ofiarny ${ }^{19}$}

W momencie gdy rodzi się drugie dziecko, ustalone są już podstawowe zasady funkcjonowania, a trudna sytuacja rodziny intensyfikuje się. Dziecko szybko zauważa, że jego starszy brat lub siostra mają wiele korzyści z bycia dobrym, grzecznym, więc przez jakiś czas próbuje zachowywać się podobnie. Niestety bez względu na 
swoje wysiłki nie jest w stanie zająć pozycji pierworodnego, więc narasta w nim złość i bunt. Cierpiąc z powodu braku uwagi, zaczyna skupiać ją w sposób negatywny - wagaruje, wdaje się w bójki, źle się uczy. Kiedy sprawia problemy wychowawcze, rodzina może odwrócić uwagę od alkoholizmu. Kozioł ofiarny bardzo wcześnie opuszcza dom rodzinny, szukając miejsca, gdzie będzie mógł rozładować swoją frustrację, i ludzi podobnych do siebie. Trafia często do grup młodocianych przestępców, narkomanów lub innych subkultur młodzieżowych. Kozioł ofiarny może być jednak zadziwiająco podobny do bohatera rodzinnego w kontekście tworzenia wizerunku rodziny. Bohater jest odpowiedzialny za pozytywną stronę, zaś kozioł - negatywną. Ma on zapewnić dobre samopoczucie rodzinie w taki sposób, by mogła zrzucić na niego winę za wszystko, co złego się w niej dzieje. Dzięki własnym zachowaniom utrzymuje w pozostałych członkach rodziny przekonanie, że alkoholizm nie jest najważniejszym problemem rodzinnym, tylko trudne dziecko. To wszystko sprzyja utrzymaniu rodzinnego status quo. Kozioł ofiarny zwykle w odwecie za koszmar dzieciństwa chce zniszczyć coś, co jest dla niego najbardziej dostępne, czyli on sam. Wcześnie sięga po alkohol i inne używki, stając się głównym kandydatem do przedłużenia linii rodzinnego alkoholizmu.

\section{Niewidzialne dziecko 20}

Pierwszych dwoje dzieci pojawia się w rodzinie na początku uzależnienia, natomiast następne przychodzi na świat, kiedy alkoholik pije ekscesywnie. Zdarza się, że takie dziecko jest niechciane, nie ma dla niego w rodzinie miejsca i roli. Przystosowuje się ono do tej trudnej sytuacji poprzez wycofywanie się, zachowuje się tak, jakby go nie było. Nie sprawia problemów, ale też nie jest dostrzegane. Nie 
pozyskuje ani pozytywnej uwagi zbieranej przez bohatera, ani negatywnej, którą obdarzany jest kozioł. Godzinami potrafi zajmować się sobą, zwykle niczego od nikogo nie chce. Ucieka w świat swoich fantazji, książek, marzeń. Odprężenia doznaje, słuchając muzyki, oglądając telewizję. W miarę dorastania stara się samodzielnie zaspokajać swoje potrzeby, dobrze czuje się w samotności. Niewidzialne dziecko w pewnym momencie przestaje rozwijać swoje umiejętności interpersonalne, w szkole wyraźnie odbiega poziomem umiejętności społecznych od swoich rówieśników. Często określane jest przez pedagogów w szkole jako „dziwne” dziecko. W życiu rodzinnym wycofanie to chroni je przed negatywnymi wpływami, ale też uniemożliwia uczestnictwo w pozytywnych interakcjach. Niewidzialne dziecko czuje się bezwartościowe i osamotnione. W dorosłym życiu może „znieczulać się” wobec przykrej rzeczywistości, od której pragnie uciec, przy pomocy narkotyków lub alkoholu, często też cierpi z powodu depresji, bulimii lub anoreksji.

\section{Maskotka $^{21}$}

Jest to najmłodsze dziecko, często już starszych rodziców, wyczerpanych uzależnieniem lub walką $\mathrm{z}$ nim. $\mathrm{W}$ rodzinie $\mathrm{z}$ problemem alkoholowym wszyscy starają się chronić najmłodsze dziecko, nie chcą powiedzieć mu prawdy o uzależnieniu rodzica. Nie uzyskuje wyjaśnienia, co dzieje się w domu, a jeśli są mu udzielane informacje, to zazwyczaj błędne, co wywołuje u maskotki ogromny lęk. Odpowiada za poprawienie nastroju rodziny i rozładowanie napięcia. Dziecko to często jest wyznaczane do roli rozjemcy i antidotum na chwile kryzysu - „Porozmawiaj z ojcem, może go udobruchasz”. Przez rodziców traktowane jest jako osoba niedojrzała, która nie rozumie, co się dzieje. Konsekwencją tego, że nikt nie traktuje maskot- 
ki poważnie, jest to, że sama zatraca granicę między tym, co należy traktować serio, a tym, co należy obrócić w żart. Sprawia wrażenie nieco młodszej, bardziej niedojrzałej od rówieśników. Kiedy musi poradzić sobie z czyjąś złością, wobec której bezsilni są domownicy, odczuwa napięcie. Ma poczucie bycia niepotrzebną, jeśli nie może poprawić komuś nastroju. Ta rola sprawia, że dziecko odłącza się od uczuć smutku i cierpienia, zawsze robiąc dobrą minę do złej gry. W dorosłym życiu często ucieka się do takiej klaunady w każdym trudnym momencie.

Przyjmując określoną rolę, człowiek uczy się, jakie uczucia może wyrażać, a jakie są niedozwolone. W rodzinie z problemem alkoholowym dzieci muszą rozwijać te cechy, które są potrzebne w zastanej sytuacji, szczególnie rodzicom, a ukryć te niepożądane. W ten sposób przyjęta przez dziecko rola staje się jego maską, zewnętrznym „ja”, pod którym skrywa swój prawdziwy charakter.

\section{Syndrom dorosłego dziecka alkoholika}

\subsection{Opis syndromu DDA}

Każde dziecko staje się kiedyś dorosłe. Doświadczenia wyniesione z dzieciństwa w rodzinie z problemem alkoholowym u wielu mężczyzn i kobiet skutkują w dorosłym życiu utrwalonymi schematami odczuwania, zachowania i myślenia. Schematy te bardzo często utrudniają normalne funkcjonowanie. Są dysfunkcyjne - sprawiają, że zależna od nich osoba cierpi z ich powodu, nie wiedząc o tym, że można coś zmienić. Nazywamy to syndromem dorosłego dziecka alkoholika ${ }^{22}$.

Nie u wszystkich osób wychowywanych w rodzinie z problemem alkoholowym objawiają się cechy syndromu DDA. Niektórzy ludzie adaptują się do trudnej rzeczywistości w sposób, który nie powoduje 
w dorosłym życiu cierpienia i bolesnych przeżyć. Sam fakt, że dana osoba wychowywała się w rodzinie, gdzie był alkoholik, nie oznacza, że od razu musi szukać pomocy psychologa.

Syndrom DDA to nie choroba. Jest to nawykowy sposób działania, doświadczania uczuć i myślenia o świecie ${ }^{23}$. Zachowania, które pozwalały przetrwać w brutalnym domu i wielu sytuacjach zagrożenia, niekoniecznie sprawdzają się w dorosłości, gdy to zagrożenie już minęło. Sytuacja psychologiczna osób z syndromem DDA przypomina sytuację osoby, która siedzi w ciemnym pokoju i boi się potworów. Wie, że one nie istnieją, ale nie może się poruszyć i odczuwa wielki strach mimo tej świadomości. Nie ma siły zapalić światła, a to przecież wiele mogłoby zmienić. Takim „światłem” okazuje się zwykle psychoterapia, która pozwala nauczyć się nowego sposobu myślenia i działania w rzeczywistości i daje możliwość poradzenia sobie z przykrymi uczuciami.

Schematy odczuwania, zachowania i myślenia są u osób z syndromem DDA często utrwalone osobowościowo ${ }^{24}$. Oznacza to, że nie są ich świadome, ale posługując się nimi, cierpią, mają trudności w kontaktach interpersonalnych oraz postrzegają zewnętrzny świat jako zagrożenie. Kobieta nauczona w dzieciństwie braku zaufania do innych może mieć problem $\mathrm{z}$ wejściem $\mathrm{w}$ satysfakcjonujący ją związek. Mężczyzna nauczony, że przemoc może służyć do osiągnięcia swoich celów, podniesie rękę na żonę, mimo że w dzieciństwie gardził takim zachowaniem u pijącego ojca.

\subsection{Cechy charakterystyczne dla osób z syndromem DDA}

Wokół dzieci alkoholików narosło wiele stereotypów. Jeśli dziecko pochodzi z rodziny z problemem alkoholowym, to z góry wiadomo, 
jakie będzie miało problemy i jak należy mu pomóc. Jest to bardzo uproszczony, a nawet błędny sposób myślenia o niezwykle zróżnicowanych trudnościach i możliwościach rozwojowych DDA. Timmen Cermak w wielu swoich książkach podkreśla, że każde dorosłe dziecko alkoholika jest jedyne w swoim rodzaju, jednak znaczące elementy jego doświadczenia są wspólne z doświadczeniami innych DDA. Te podobieństwa ujął w listę cech charakterystycznych dla osób z syndromem $\mathrm{DDA}^{25}$, aby jak najlepiej zrozumieć, z czym zmagają się one na co dzień, i pomóc im na początkowym etapie leczenia. Są to:

- lęk przed utratą kontroli (staram się nie reagować zbyt emocjonalnie; lubię, kiedy wszystko jest na swoim miejscu; czułbym się znacznie lepiej, gdybym miał większy wpływ na to, co się dzieje; czuję się zaniepokojony, kiedy mam świadomość, że nie panuję nad wszystkim);

- lęk przed uczuciami (trudno mi wyrażać uczucia; często nie jestem świadom swoich uczuć, czasami myślę, że są wyłącznie ciężarem; przeraża mnie, czego mógłbym się dowiedzieć, gdybym sobie pozwolił na jakiekolwiek uczucia; w mojej rodzinie nie można było okazywać negatywnych uczuć);

- lęk przed konfliktem (jeśli pojawia się konflikt, staram się go unikać; uważam, że konflikty są czymś złym i prowadzą do przemocy; za wszelką cenę staram się uniknąć konfliktu, dostosowuję się, zmieniam plany);

- nadmiernie rozwinięte poczucie odpowiedzialności (mam skłonność do poczucia odpowiedzialności za wszystko; jeżeli trzeba wykonać jakąś dodatkową pracę, zgłaszam się na ochotnika; trudno mi odmówić, kiedy ktoś prosi mnie o pomoc);

- poczucie winy (czuję się winny za odczuwanie jakichkolwiek własnych potrzeb; często czuję się winny za bycie ciężarem dla słych dzieci alkoholików, tłum. P. Żak, Kielce 2011, s. 118-133. 
innych; ciągle za wszystko przepraszam; przepraszam za rzeczy, które nie wymagają przeprosin);

- niezdolność do odprężenia się oraz do spontanicznej zabawy (kiedy ludzie śmieją się zbyt głośno, zaczynam odczuwać niepokój, zabawa jest dla mnie trudnym zadaniem; w znacznej mierze jestem samotnikiem; mam skłonność, by nie śmiać się bez uprzedniego sprawdzenia, czy inni się śmieją);

- ostra, bezlitosna samokrytyka (jestem dla siebie najsurowszym krytykiem; zbyt szybko się osądzam; jestem swoim najgorszym wrogiem; w mojej rodzinie nigdy niczego nie robiłem dobrze; w mojej rodzinie za każdy błąd ponosiło się straszne konsekwencje);

- życie w świecie zaprzeczeń (kiedy czuję się zagrożony, przyjmuję pozycję obronną; czasem wolę skłamać niż przyznać się do popełnionego błędu);

- pozostawanie w roli ofiary (często czuję się bezradny; mam wrażenie, że cokolwiek bym zrobił, niczego to nie zmieni; zawsze ktoś sprzątnie mi sprzed nosa to, czego potrzebuję);

- zachowania kompulsywne (nałogowy lub obsesyjny stosunek do np. punktualności, jedzenia, alkoholu, seksu, pracy, robienia zakupów, hazardu, praktyk religijnych);

- tendencja do mylenia miłości z litością (przyciągają mnie ludzie, którym mogę pomóc lub których mogę wyleczyć; największą bliskość odczuwam wówczas, gdy komuś pomagam; mam skłonność do nawiązywania relacji z osobami, które zostały zranione lub są niedostępne);

- lęk przed odrzuceniem (odejście jest dla mnie niezwykle trudne; nienawidzę mówić „żegnaj”; pozostawałem w bliskich związkach o wiele za długo, niż powinienem; kiedy ktoś bliski wyjeżdża, boję się, że nigdy więcej go nie zobaczę);

- myślenie kategoriami „białe” lub „czarne” (zawsze wydaje mi się, że tylko jedna odpowiedź jest prawidłowa; mam skłonność do myślenia w kategoriach dobro-zło; jeżeli ty masz rację, to ja na pewno się mylę); 
- zalegający żal (staram się unikać mówienia o mojej rodzinie; tak bardzo próbuję nie myśleć o przeszłości, a wciąż mnie prześladuje; pamiętam, jak mówiono mi: „nie denerwuj się”);

- zdolność przetrwania (często czuję się jak bojownik, któremu udało się przetrwać; często mam wrażenie, że po tym, co przetrwałem $\mathrm{w}$ dzieciństwie, dam sobie radę z każdą sprawą; przetrwanie umożliwiła mi moja niezależność; nauczyłem się, że nie mogę na nikim polegać).

Te wszystkie cechy nasilają u osób z syndromem DDA przykre uczucia, z którymi nie potrafią sobie same poradzić ${ }^{26}$. Przeżywając je, zaczynają odsuwać się stopniowo od ludzi i potwierdzają tym tylko swoje przekonanie na temat wrogo nastawionego do nich świata. Zaczynają wtedy brnąć w ciąg tych samych, szkodliwych myśli, uczuć i zachowań. Takie błędne koło to samospełniające się proroctwo. Aby je przerwać i być bardziej świadomym swoich uczuć, które dokuczliwie zatruwają życie, warto zgłosić się na terapię.

\subsection{Wsparcie dla dorosłych dzieci alkoholików}

Kim są dorosłe dzieci alkoholików, kiedy mają już świadomość swoich słabości i chcą zawalczyć o siebie, bardzo dobrze opisuje fragment książki pt. 12 kroków dla dorosłych dzieci z uzależnieniowych i innych rodzin dysfunkcyjnych ${ }^{27}$ :

Dorastaliśmy w rodzinach dysfunkcyjnych. Ich środowisko wypaczyło nasze myślenie o nas samych i o otaczającym nas świecie. Widząc siebie w krzywym zwierciadle informacji i sygnałów dawanych nam przez naszych rodziców, uwierzyliśmy, że jesteśmy „nie w porządku”. Zostaliśmy pozbawieni naszej autentycznej tożsamości i zaczęliśmy

2712 kroków dla dorosłych dzieci z uzależnieniowych i innych rodzin dysfunkcyjnych, praca zbiorowa, Warszawa 1996, s. 2. 
szukać sposobów na dobre samopoczucie. Chociaż wyglądamy jak dorośli, nadal zachowujemy się jak dzieci i pozwalamy, aby inni mieli wpływ na nasze myślenie o sobie, nasze poczucie własnej wartości i nasze szczęście. Nasze nieprawidłowe myślenie było przyczyną tego, że podejmowaliśmy decyzje, które nas niszczyły. Dlatego też chcemy przestać poprawiać własne samopoczucie nieskutecznymi zachowaniami, nadużywaniem innych ludzi, seksem, substancjami odurzającymi, manią posiadania, manią sukcesu, pieniędzmi itp.

Te słowa również bardzo dobrze odnoszą się do tego, w jakim kierunku powinny podążać leczenie i pomoc. Potrzeba psychoterapii jest zdrowym objawem i przejawem dojrzałości osoby, która chce lepiej zrozumieć siebie i rządzące nią mechanizmy. Podczas terapii DDA uświadamia sobie, że nie cofnie czasu i nie zmieni przeszłości, może za to zrobić wiele, aby przykre wspomnienia przestały nim rządzić. Kiedy zdaje sobie sprawę, co ma wpływ na wszystkie odczucia, myśli, zachowanie, może poczuć się wolne i zyskać wolność wyboru, co dla niego jest dobre ${ }^{28}$. Może wtedy uniknąć zachowań dysfunkcyjnych i wybierać te prawidłowe, dzięki którym zaprowadzi ład i porządek w swoich planach oraz w relacjach $\mathrm{z}$ bliskimi i w traktowaniu siebie. W psychoterapii bardzo istotne jest to, że poznając głęboko skrywane w sobie uczucia, DDA przekonują się, że nawet te przykre, jak smutek, złość, lęk, nie są w stanie ich osłabić, a wręcz przeciwnie - pomagają bardziej świadomie cieszyć się życiem.

\section{Metodologia badań własnych}

\section{Przedmiot i cel badań}

Przedmiot badań jest zadaniem, które mamy do wykonania, i zależy od tego, jaki rodzaj badań zamierzamy przeprowadzić. Badanie 
naukowe to różne działania mające na celu poznanie w sposób dokładny i rzetelny zjawisk i procesów społecznych, na których chcieliśmy się skupić. Aby zachować sens, każde badanie służy realizacji celu określonego przez autora. Celem badań własnych jest chęć wzbogacenia wiedzy o osobach, rzeczach lub zjawiskach, które są przedmiotem badań. Przez cel badań należy rozumieć rodzaj efektu, jaki zamierzamy uzyskać w ich wyniku, a także rodzaj czynników związanych z tymi efektami. Głównie pytanie, jakie należy postawić, to w jakim celu badamy i co chcemy dzięki temu osiągnąć ${ }^{29}$.

Przedmiotem badań pracy jest uzyskanie informacji na temat tego, czy wychowanie się w rodzinie alkoholowej ma swoje konsekwencje przy wyborze współmałżonka. Celem nadrzędnym jest sprawdzenie, jakie czynniki wyniesione z rodzinnego domu mogą przyczyniać się do trudności w znalezieniu odpowiedniego partnera i w jaki sposób wpływają one na budowanie relacji przez dorosłe dzieci alkoholików. Dodatkowy cel stanowi szersze przyjrzenie się osobom z syndromem DDA.

\section{Problemy badawczy oraz hipotezy badawcze}

Prace badawcze zmierzają do poznania rzeczywistości, zjawiska i instytucji, bądź to dla uzyskania wiedzy o ich stanie, przebiegu, rozwoju, bądź dla podjęcia kroków ku ich zmianie, poprawie, bądź jeszcze dla zdobycia podstaw do uogólnień, zbudowania definicji czy poznania praw określających prawidłowości ich rozwoju. Punktem wyjścia do badań nad wpływem wychowania się w rodzinie z problemem alkoholowym na wybór współmałżonka była analiza literatury przedmiotu i własne przemyślenia nad sformułowaniem problemu i hipotez ${ }^{30}$.

Według Tadeusza Pilcha problemy badawcze są to pytania, na które szukamy odpowiedzi na drodze badań naukowych. Odpowiedzi 
na te pytania należy szukać przez własny wysiłek, nie oczekując gotowej odpowiedzi. Skuteczne przeprowadzenie badania naukowego wymaga oprócz postawienia problemów badawczych również sformułowania hipotez. Stanowią one stwierdzenia, co do których istnieje pewne prawdopodobieństwo, że są właściwym rozwiązaniem postawionych problemów badawczych ${ }^{31}$.

Główny problem mojej pracy badawczej dotyczył tego, czy i jakie konsekwencje dla budowania bliskich związków w dorosłym życiu ma wychowanie $\mathrm{w}$ rodzinie $\mathrm{z}$ problemem alkoholowym.

Dla sprawdzenia tego problemu zostały sformułowane następujące hipotezy:

1. Dorosłe dzieci alkoholików poszukują partnerów i modelu relacji będących przeciwieństwem modelu, jaki prezentowali rodzice.

2. Dorosłe dzieci alkoholików mają trudności w wyborze partnera, przejawiające się w wielu niewłaściwych zachowaniach wobec nawiązywania relacji.

3. Samoocena i poczucie wartości u dorosłych dzieci alkoholików są niskie, co decyduje o wyborze partnera i tym, z jakimi trudnościami mogą spotkać się, będąc w związku.

4. Oczekiwania dorosłych dzieci alkoholików wobec partnera dotyczą zaspokojenia tych potrzeb, których nie zaspokoili w dzieciństwie ich rodzice.

5. Dorosłe dzieci alkoholików mają trudności w relacjach z partnerem, które mogą być związane z nieprawidłowym stylem przywiązania wytworzonym w dzieciństwie.

\section{Metoda badawcza}

Metoda badań jest to zespół teoretycznie uzasadnionych zabiegów koncepcyjnych i instrumentalnych, obejmujących najogólniej ca- 
łość postępowania badacza zmierzającego do rozwiązania określonego problemu badawczego. Wielu specjalistów metodologii badań określa metodę jako sposób dochodzenia do prawdy, umożliwiający formułowanie uzasadnionych i sprawdzonych twierdzeń. Głównym zadaniem w każdej pracy naukowej jest znalezienie takich metod badawczych, które pozwoliłyby rozwiązać postawione problemy w sposób rzetelny i dokładny ${ }^{32}$.

W swojej pracy posłużyłam się metodą sondażu diagnostycznego, a narzędziem był kwestionariusz ankiety. Ankieta jest techniką gromadzenia informacji polegającą na wypełnianiu samodzielnie przez badanego specjalnych kwestionariuszy, w obecności lub częściejnieobecności ankietera. W naukach społecznych posiada zasadnicze znaczenie dla rozwoju wiedzy teoretycznej i diagnostyczno-opisowej $^{33}$. Kwestionariusz ankiety zbudowany był z 36 pytań, w większości zamkniętych. Na początku znalazło się krótkie wprowadzenie dotyczące tematu pracy licencjackiej i badań oraz przedstawienia osoby, która przeprowadza badanie. Poniżej została umieszczona metryczka odnosząca się do płci, wieku, miejsca zamieszkania oraz wykształcenia respondentów. Dalsza część ankiety została podzielona na trzy części:

- pytania wprowadzające, dotyczące obecnego statusu związku, oczekiwań wobec partnera i stosunku do bycia w relacji z nim;

- pytania odnoszące się do obecnej bądź poprzedniej relacji, tego, jak układa lub układało się w związku, jakie trudności napotykają osoby z syndromem DDA i jak sobie z nimi radzą w związku;

- pytania dotyczące rodziców, relacji pomiędzy nimi oraz uczuć DDA względem nich.

Ankieta została przeprowadzona wśród 30 osób - dorosłych dzieci alkoholików. Były to w większości osoby w trakcie lub po 
zakończonej terapii w Ośrodku Psychoterapii Dorosłych Dzieci Alkoholików w Krakowie. Ankietowanym zapewniono pełną anonimowość.

\section{a. Charakterystyka grupy badawczej}

Jak już zostało wspomniane, badana grupa składała się z 30 osób dorosłych dzieci alkoholików. Przedział wiekowy badanych to 1850 lat. Najwięcej osób należało do grup 18-24 i 25-34 lata, gdyż razem 27 osób (9o proc.). Większość stanowiły kobiety - 19 osób (63 proc.). Wyższe wykształcenie posiadało 18 osób (6o proc.), średnie 11 (37 proc.), a zawodowe jedna osoba (3 proc.). Miasto jako miejsce zamieszkania wskazało 25 osób (83 proc.), pozostałe 5 osób mieszka na wsi (17 proc.).

\section{Interpretacja wyników}

Problem badawczy mojej pracy dotyczył tego, czy i jakie konsekwencje dla budowania bliskich związków w dorosłym życiu ma wychowanie się w rodzinie z problemem alkoholowym. Problematyka DDA porusza wiele kwestii, szczególnie zwracając uwagę na to, co dzieje się w rodzinie z problemem alkoholowym, gdy przebywa w niej dziecko. Rzadko zwraca się uwagę na to, jak radzi sobie ono w dorosłości i w jaki sposób ważna, życiowa decyzja, tj. wybór współmałżonka, może być zdeterminowana przez atmosferę domu rodzinnego. Za pomocą hipotez spróbowałam sprawdzić, czy taki problem występuje wśród osób z syndromem DDA.

Pierwsza hipoteza to: dorosłe dzieci alkoholików poszukują partnerów i modelu relacji będących przeciwieństwem modelu, jaki prezentowali rodzice. Na początku trzeba zapytać, czy DDA wiążą się z osobami z rodziny z problemem alkoholowym lub z alkoholikami. W obu przypadkach badani w dużej większości wystrzegają się takich związków, by nie zwiększać swojej szansy na powtórzenie 
koszmaru z domu rodzinnego. W pytaniu dotyczącym oczekiwań spora część osób zaznaczyła, że partner nie może być uzależniony od alkoholu lub innych używek. Będąc często świadkami kłótni, braku szacunku w relacji pomiędzy rodzicami, poszukują u partnera zupełnie innych cech, mając nadzieję na zbudowanie zdrowej relacji. Wśród odpowiedzi DDA na temat tego, co cenią najbardziej w związku między dwojgiem ludzi, najczęściej powtarzało się: zrozumienie, szczerość, szacunek, wsparcie, zaufanie, miłość. Natomiast w pytaniu o to, jaki powinien być idealny partner, wskazywali na takie cechy jak: kochający, odpowiedzialny, wyrozumiały, bez nałogów. Wszystkie te odpowiedzi wskazują, jak bardzo dorosłe dzieci alkoholików pragną ciepła i miłości i zdają sobie sprawę z tego, jak ważne jest to w relacji, mimo że model wypracowany przez rodziców często był zaburzony i zakłamany ze względu na współuzależnienie jednego z nich. Taki zły wzorzec stosunków pomiędzy rodzicami potwierdził się w pytaniu dotyczącym tego tematu. Najczęściej padała odpowiedź, że wszystko zmieniało się pod wpływem picia jednego z rodziców oraz układało się między nimi dobrze tylko wtedy, gdy rodzic był trzeźwy. Sytuacja w rodzinie z problemem alkoholowym $\mathrm{z}$ tego względu jest bardzo niestabilna i trudno w takich warunkach zbudować coś trwałego. Do tego pojawiały się odpowiedzi wskazujące na angażowanie dzieci w kłótnie i wzajemne narzekanie na siebie, a to prowadzi do tego, że dziecko musi stanąć po stronie któregoś z opiekunów i wykazać się niezdrową lojalnością. Dorosłe dzieci alkoholików wskazywały również w pytaniach na temat relacji, jak bardzo ważne jest dla nich to, że mogą liczyć na swojego partnera, ponieważ $\mathrm{w}$ dzieciństwie często rodzic nie dotrzymywał obietnic i nie był osobą, u której można było znaleźć wsparcie. W pytaniu na temat przebiegu konfliktu większość osób odpowiedziała, że kłótnie się zdarzają, ale bez obrażania drugiej strony, jakby ze strachu przed tym, czego byli świadkami, gdy rodzice często ranili siebie słowami, co niekiedy mogło prowadzić nawet do różnych form przemocy fizycznej. 
Dorosłe dzieci alkoholików mimo wielu negatywnych doświadczeń wyniesionych z rodzinnego domu oczekują od partnera, że ich relacje będą pozytywne, a uczucia pełne miłości. Dowodzi to też temu, jak bardzo im tego w dzieciństwie brakowało i w jak dużym stopniu pragną, by ich życie z drugim człowiekiem wyglądało zupełnie inaczej niż to, co obserwowali pomiędzy swoimi rodzicami.

Druga hipoteza to: dorosłe dzieci alkoholików mają trudności $\mathrm{w}$ wyborze partnera, przejawiające się w wielu niewłaściwych zachowaniach wobec nawiązywania relacji. Należy zacząć od tego, że jedna trzecia badanych nie posiada żadnego partnera, a duża część osób będących w relacji z partnerem tworzy związek niesformalizowany, w którym para mieszka ze sobą lub nie. Procent tych osób jest równy procentowi związków sakramentalnych wśród ankietowanych. Większość ma doświadczenie w poprzednich związkach, co może świadczyć o tym, że DDA trudno jest zdecydować się na wybór partnera na całe życie. Poprzednie związki badanych trwały zwykle średnio kilka miesięcy, do roku, czyli w czasie, kiedy mija pierwsze, wielkie zauroczenie i nadchodzi moment, w którym pojawiają się głębsze uczucia i istnieje szansa na stworzenie poważnej relacji. To może świadczyć o tym, że dorosłe dzieci alkoholików boją się momentu wytworzenia bliskiej więzi z drugim człowiekiem. W pytaniu dotyczącym podejmowania relacji pojawiło się wiele dowodów na to, jak trudno jest dzieciom $\mathrm{z}$ domów z problemem alkoholowym uwierzyć w to, że w spotkaniu z drugą osobą czeka je coś dobrego. Najczęściej wybieranymi odpowiedziami charakteryzującymi je w kwestii podejmowania relacji były te mówiące o tym, że szukają one potwierdzenia własnej wartości u innych, są nieufne, brakuje im wiary w to, że ktoś je pokocha takimi, jakimi są, oraz odczuwają strach przed odrzuceniem. Tylko jedna osoba odpowiedziała, że nie lubi poznawać nowych ludzi, co może dowodzić temu, że DDA bardzo chcą nawiązywać relacje, ale wszystkie wymienione wyżej lęki sprawiają, że są na to zablokowane i wolą często żyć samotnie 
lub tkwić w niesatysfakcjonującym związku niż ryzykować kolejnym zranieniem przez bliską osobę. Badani, którzy zadeklarowali, że obecnie są w związku, przyznali też, że w trakcie jego trwania zdarzały się rozstania, najczęściej z ich własnej inicjatywy, co również mogło wypływać z lęków i wątpliwości, czy życie we dwoje ma sens i czy wybrany partner jest tym właściwym.

Wśród dorosłych dzieci alkoholików pojawia się sporo trudności $\mathrm{w}$ wyborze partnera, związanych z wieloma lękami, niską samooceną i brakiem wiary w siebie. Krytyka i brak troski ze strony rodziców pozostawiły w nich ślad i aby mogły stworzyć związek i zaufać drugiej osobie, często potrzebują terapii. Nadzieję na to, że mimo różnych negatywnych doświadczeń może się udać, daje fakt, że dwie trzecie ankietowanych jest w związku. W tej grupie 20 proc. to osoby będące w związkach ze stażem ponad dziesięcioletnim, które zawarły sakramentalny związek małżeński, nie bojąc się zaryzykować wyboru partnera na całe życie.

Trzecia hipoteza to: samoocena i poczucie wartości u dorosłych dzieci alkoholików są niskie, co decyduje o wyborze partnera i tym, z jakimi trudnościami mogą spotkać się, będąc w związku. Respondenci zapytani na początku o ocenę własnej atrakcyjności w większości odpowiedzieli, że nie są do końca zadowoleni, wyglądają dobrze, ale mogłoby być lepiej. Jedna piąta nie podoba się sobie, a tylko trzy osoby oceniły swoją atrakcyjność bardzo dobrze. DDA za to dużo lepiej oceniły atrakcyjność swojego partnera - aż 93 proc. badanych twierdzi, że jest on atrakcyjny lub bardzo atrakcyjny. Na podstawie tych odpowiedzi widać, że respondentów cechuje niska samoocena i brak zadowolenia ze swojego wyglądu, za to mniej krytycznie odnoszą się w tym aspekcie do swoich wybranków. Takie postrzeganie siebie może prowadzić do pojawiania się różnych problemów w relacji, takich jak zazdrość czy lęk przed odrzuceniem. Część DDA w pytaniu o zazdrość przyznawała się do niej, argumentując przy tym, że trochę tego uczucia w związku nie zaszkodzi. Druga część również odpowiedziała, że jest zazdrosna, ale stara się z tym walczyć. 
Pozostałe odpowiedzi, tj. mam duży problem z zazdrością, nie mam powodów do zazdrości lub zazdrość niszczy związek, pojawiły się, ale w mniejszości. Warto też zauważyć, że żadna z osób nie zaznaczyła odpowiedzi, że zazdrość jest spowodowana zachowaniem partnera, tym, że może on dawać do tego typu uczuć powody. Sugeruje to, że w większości owo doznanie może wynikać z niskiej samooceny i poczucia własnej wartości, a nie z konkretnych powodów czy sytuacji, które dostarcza partner. $\mathrm{Z}$ takiego obrazu siebie mogą również wynikać obawy DDA dotyczące odrzucenia. Połowa badanych przyznała, że od czasu do czasu przeżywa strach przed rozstaniem. Reszta odpowiedziała, że ciągle się tego obawia lub taka obawa towarzyszyła im na początku związku. DDA czują się mało wartościowe i trudno im uwierzyć, że ktokolwiek chce tworzyć z nimi relacje, jeśli nawet rodzice nie okazywali im zainteresowania i czułości. Ze strachu przed tym, że mogą ponownie zostać zranione, same często kontrolują partnera. Większa część ankietowanych przyznała, że kontroluje to, co dzieje się w związku, ponieważ to daje jej poczucie bezpieczeństwa - to właśnie ono jest często argumentem, podstawą kontroli. DDA czują się spokojniejsze, gdy wydaje im się, że mają na wszystko wpływ i taką moc, by nad wszystkim zapanować. Prawie jedną trzecią stanowiły osoby sprawujące w związku kontrolę, ale starające się nie śledzić wszystkiego dookoła, natomiast pozostali odpowiedzieli, że nie da się kontrolować wszystkiego lub że to partner jest stroną kontrolującą.

Niska samoocena i poczucie własnej wartości mogą mieć zgubny wpływ na wybór partnera i tworzenie relacji. Konsekwencją tak zaburzonego obrazu siebie w przypadku DDA może być wybieranie niewłaściwych partnerów, często uzależnionych, i powielanie schematów $\mathrm{z}$ domu rodzinnego. Jest to zwykle spowodowanie potrzebą bycia kochanym i chcianym, a także innymi, które nie zostały zaspokojone w dzieciństwie przez rodziców.

Czwarta hipoteza to: oczekiwania dorosłych dzieci alkoholików wobec partnera dotyczą zaspokojenia tych potrzeb, których nie za- 
spokoili w dzieciństwie rodzice. $\mathrm{W}$ rodzinie z problemem alkoholowym dzieci najczęściej są zostawione same sobie, ponieważ alkoholik skupia w niej największą uwagę. Trudno też wtedy o zaspokojenie naturalnych potrzeb każdego człowieka dotyczących uczuć i miłości. Dorosłe dzieci alkoholików chcą to wszystko nadrobić, najczęściej w związku z partnerem. Ankietowani poproszeni o scharakteryzowanie rodzica uzależnionego z perspektywy, gdy byli dziećmi, oraz obecnej, jako dorośli, wskazywali na wiele aspektów zaniedbań z jego strony. Jeśli chodzi o perspektywę, kiedy byli dziećmi, najczęściej pojawiały się odpowiedzi takie jak: „rodzic był agresywny, bałem/am się go” oraz „nigdy nie dotrzymywał danych obietnic”. DDA wskazywały też, że rodzic był nieobliczalny oraz rozmowny tylko wtedy, gdy się napił. Badani jednak starają się zapamiętać również dobre momenty, ponieważ wiele odpowiedzi dotyczyło wspomnień związanych ze wspólną zabawą i miłym spędzaniem czasu z rodzicem uzależnionym. Z perspektywy osoby dorosłej pojawia się więcej przykrych stwierdzeń. Najczęściej DDA oceniają rodzica jako człowieka słabego i nieodpowiedzialnego, z problemami emocjonalnymi. Badani w większości uważają też, że rodzic uzależniony nigdy nie dojrzał do swojej roli. $Z$ tych wszystkich powodów tak bardzo szukają u swoich partnerów czegoś zupełnie innego, co zaspokoi ich potrzeby niespełnione w dzieciństwie.

Pragnienie zaspokojenia potrzeb potwierdza się w pytaniu o oczekiwania wobec partnera. Wśród najważniejszych DDA wymieniały: będzie mnie kochał i szanował, okaże mi wsparcie, będzie odpowiedzialny, będzie dobrym rodzicem, da mi poczucie bezpieczeństwa. Są to podstawowe przymioty, którymi cechuje się zdrowa relacja pomiędzy małżonkami, a których DDA rzadko doświadczały jako dzieci ze strony swoich rodziców.

Piąta hipoteza to: dorosłe dzieci alkoholików mają trudności w relacjach z partnerem, które mogą być związane z nieprawidłowym stylem przywiązania wytworzonym w dzieciństwie. Wśród dzieci alkoholików istnieje duże prawdopodobieństwo do ukształtowania 
się pozabezpieczanych stylów przywiązania. DDA różnią się od swoich rówieśników stylem przywiązania i częściej ujawniają jeden z nich: unikający, zdezorganizowany lub ambiwalentny. Wśród badanych 93 proc. posiada ojca uzależnionego od alkoholu, tylko 3 proc. matkę. Doświadczenia dziecka w relacji z matką są podstawą tworzenia się wewnętrznych modeli przywiązania, które determinują jego rozwój. Jeśli matka jest alkoholiczką lub współuzależnioną, nie sprzyja to kształtowaniu się bezpiecznych stylów przywiązania z powodu wielu napięć, problemów, jakie ona przeżywa. Może się to wiązać również z uczuciami, jakie dorosłe dzieci alkoholików mają względem rodziców. Wobec rodzica uzależnionego najczęściej pojawiały się: żal, poczucie krzywdy, bezradność. Uczucia wobec rodzica współuzależnionego, czyli w przypadku badanych najczęściej matki, to: zmartwienie, współczucie, bezradność, żal. Wszystkie te, często tłumione w sobie, uczucia mogą być przenoszone na partnera i powodować przez to wiele trudności w relacji. Potwierdzają to również pytania dotyczące poprzednich związków. Prawie połowa badanych DDA miała już za sobą wcześniejsze doświadczenia. 58 proc. tych związków przetrwało mniej niż rok. Może świadczyć to o wielu problemach w zbudowaniu trwałej relacji. Warto też jednak zauważyć, że obecny partner jest pierwszym, z którym są w poważnym związku - dotyczy to 37 proc. badanych. Zastanawiać może natomiast ilość posiadanych dzieci w związkach dorosłych dzieci alkoholików. Aż 83 proc. respondentów nie ma dzieci, a 10 proc. - tylko jedno. Prawie połowa DDA biorących udział w badaniu to osoby w wieku 25-34 lata, czyli najlepszym okresie na planowanie rodzicielstwa. Może to ukazywać kolejny problem tej grupy, czyli strach przed tym, by nie być dla swojego dziecka takim rodzicem, jakiego każdy z jej członków sam posiadał. Zdarza się, że tkwi w nich przekonanie, że dla ich syna czy córki życie okaże się równie trudne i bolesne.

Nieprawidłowe style przywiązania niosą ze sobą wiele szkód dla dziecka. Najmocniej ich skutki odczuwane są w dorosłości, gdy DDA 
stają przed wyborem osoby na całe życie. Wpływa to również na jakość relacji w tworzonym przez nie związku. Trudności dotyczą najczęściej: unikania bliskości i kontaktu, negatywnych uczuć wobec siebie i rodziców, niskiego poczucia własnej wartości oraz obaw przed odrzuceniem i rodzicielstwem. Wszystkie wyżej wymienione, również w poprzednich hipotezach, lęki i problemy potwierdziły się w badaniach.

Dorosłe dzieci alkoholików mają wiele trudności w budowaniu i utrzymaniu relacji oraz związków interpersonalnych. Konsekwencją tego jest mniej udane tworzenie więzi i funkcjonowanie w kontaktach z drugą osobą. Często objawia się to np. brakiem zaufania, zazdrością, kontrolą lub lękiem przed porzuceniem przez partnera, co z kolei wynika z niewłaściwego rozwoju dziecka w rodzinie z problemem alkoholowym. Jednak pomimo wielu problemów w relacji do siebie i drugiego człowieka DDA wykazują dużo cech pozytywnych, a także sporo godnych uwagi umiejętności. Dzięki nim mogły wygrać z przeciwnościami losu.

\section{Wnioski}

- Wychowanie w rodzinie z problemem alkoholowym nie sprzyja budowaniu i odkrywaniu obrazu samego siebie.

- Kłopoty tej grupy z właściwym postrzeganiem rzeczywistości powodują różnego rodzaju zaburzenia związane z syndromem DDA.

- Rodzina z problemem alkoholowym wpływa niekorzystnie na psychiczne funkcjonowanie dziecka, skutkując w dorosłości poczuciem wyobcowania, niską samooceną i kłopotami z budowaniem bliskich relacji.

- Konsekwencją wychowania w rodzinie z problemem alkoholowym jest często trudniejsze tworzenie bliskich relacji.

- Dorosłe dzieci alkoholików poszukują partnerów i modelu relacji będących przeciwieństwem modelu, jaki prezentowali rodzice. 
- Niska samoocena i poczucie wartości u dorosłych dzieci alkoholików utrudniają im normalne funkcjonowanie i wpływają na pojawiające się w związku trudności.

- Oczekiwania dorosłych dzieci alkoholików wobec partnera dotyczą zaspokojenia tych potrzeb, których nie zaspokoili w dzieciństwie rodzice.

\section{Zakończenie}

Rodzina z problemem alkoholowym to obszerny i wymagający temat. Mimo wielu publikacji i literatury o alkoholizmie mało poświęca się w nich miejsca na odmalowanie dokładnego portretu dzieci alkoholików. Niewiele też można znaleźć wątków dotyczących wyboru współmałżonka czy relacji takich osób z innymi ludźmi. Często za to natrafia się na stereotypową opinię, że ich partnerami z dużym prawdopodobieństwem mogą zostać alkoholicy i tak tworzy się kolejne pokolenie rodziny skażonej tą chorobą; taki osąd z pewnością sprawia przykrość wielu osobom z syndromem DDA. Dzięki tej pracy, a szczególnie badaniom, mogłam poznać inne oblicze tych osób. Trudne dzieciństwo nie przekreśla możliwości, jakie daje dorosłość. Na szczęście dla wielu DDA doświadczenia wyniesione z domu rodzinnego, choć ważne i trudne, nie zawsze determinują ich przyszłość. Każde dzieciństwo, nawet spędzone w rodzinie z problemem alkoholowym, daje szansę na osobistą i duchową przemianę. Bez względu na to, z jakiej rodziny się wywodzimy, mamy szansę na stworzenie szczęśliwego związku, jeśli tylko włożymy w to miłość i pracę.

Dalsze pogłębianie wiedzy na temat osób z syndromem DDA jest potrzebne, by lepiej poznać i zrozumieć ich naturę. Warto też zauważyć tutaj drugą stronę, czyli osoby będące w związku z dorosłymi dziećmi alkoholików. Dla nich ta wiedza jest szczególnie ważna, gdyż często nie mają pojęcia, jak postępować w kryzysowych momentach, np. kiedy mąż czy żona nagle oddala się, zamyka się w sobie bądź na wszystko reaguje gniewem lub płaczem. 
W tym miejscu chciałabym też podziękować tym osobom, które pomogły mi w przygotowaniu niniejszej pracy i okazały wsparcie. Szczególne wyrazy wdzięczności należą się tu pani dr Bożenie Gulli, która jako promotor motywowała i zawsze służyła radą, wszystkim biorącym udział w ankiecie dorosłym dzieciom alkoholików i znajomym, którzy w jakikolwiek sposób przyczynili się do powstania tej pracy. 